\title{
Evaluating the Efficiency of Financial Inclusion (Special reference to Jharkhand, India)
}

\author{
Suman Palit ${ }^{a}$ and NiladriDas ${ }^{b^{*}}$ \\ ${ }^{2}$ Project fellow, Indian school of Mines, Dhanbad, India \\ ${ }^{b}$ Assistant professor, Indian school of Mines, Dhanbad, India
}

\begin{abstract}
This paper is an attempt to analyze the status of financial inclusion in the state of Jharkhand, India. It tries to evaluate the efficiency of the financial institutions in terms of their outreach to clients and overall client satisfaction. Responses were collected separately from the service providers and customers through two different questionnaires and a convenience sampling method was adopted to select the respondents. Hypotheses development and testing was done to analyze data using a regression model. The first questionnaire examined the relationship between various financial inclusion determinants with "Outreach" and the second questionnaire studied the relationship between financial inclusion determinants with "Customer satisfaction." The empirical results of the study exhibit that the financial inclusion determinants have a positive effect on the outreach to clients and overall customer satisfaction levels and improve the customers' financial as well as their social capital base. This in turn fosters the financial inclusion activity in the region.
\end{abstract}

Abstrak: Paper ini merupakan upaya untuk menganalisis status inklusi keuangan di negara bagian Jharkhand, India, dan mencoba mengevaluasi efisiensi lembaga keuangan dalam hal jangkauan mereka untuk klien dan kepuasan klien secara keseluruhan. Tanggapan dari kuesioner yang dikumpulkan secara terpisah dari penyedia layanan dan pelanggan melalui dua kuesioner yang berbeda dan metode convenience sampling diadopsi untuk memilih responden. Pengembangan hipotesis dan pengujian dilakukan untuk menganalisis data menggunakan model regresi. Kuesioner pertama, meneliti hubungan antara berbagai faktor penentu inklusi keuangan dengan "outreach," dan kuesioner kedua mempelajari hubungan antara faktor-faktor penentu inklusi keuangan dengan "kepuasan pelanggan." Hasil empiris dari studi ini bahwa penentu inklusi keuangan memiliki efek positif pada penjangkauan kepada klien dan tingkat kepuasan pelanggan secara keseluruhan dan meningkatkan pelanggan keuangan serta basis modal sosial mereka. Hal ini pada gilirannya mendorong aktivitas inklusi keuangan di wilayah tersebut.

Keywords: customer satisfaction; financial inclusion; microfinance institutions; NGO's; outreach

JEL classification: G21, L31

* Corresponding author's e-mail:niladri_pnu2003@yahoo.co.in 


\section{Introduction}

Recently the issue of financial inclusion has received much attention from the researchers and policy makers all over the world. Financial inclusion is the delivery of financial services at affordable cost to sections of disadvantaged and low-income segments in society. In the context of the financial institutions, it deals with the spread of their services among various sections of society.

"Microcredit, or microfinance, is managing an account for the unbankable, bringing credit, empowering investment funds and making other key money related administrations within the reach of a large number of individuals who are too poor to possibly be served by customary banks, on the grounds that, in the vast majority of cases, they are not able to offer adequate insurance. When all is said and done, banks are for individuals with cash, not for individuals without cash," (Balkom et al. 2009). "The plan of microfinance, is accordingly, essentially the procurement of an extensive variety of monetary administrations, for example, stores, advances, installment administration and protection to poor and low wage family units," (ADB 2008).

In the context of the above definition, microfinance is the provision of financial services to those who have been neglected by the mainstream banking system. Some plausible reasons for this neglect could be that the clients are poor, lacking in education, residing in remote areas, ignorant about banking rules etc. Microfinance was perceived as one of the most promising and sustainable ways to tackle poverty alone, as it is usually presented as a package of financial services to the poor to improve their living standards. Microfinance is thought to enhance access to education, health services, water and social services. In other words, financial inclusion activities are a barometer of economic growth for any country, state, or region in particular.

\section{Background to The Study}

The failure of commercial banking to provide financial services to the poor, coupled with the disadvantages of using informal markets, are major rationales for the intervention in the market of financial services at the micro level. Consequently, microfinance emerged as an economic development approach intended to address the financial needs of the deprived groups in society. The term microfinance alludes to "The procurement of monetary administrations to lowwage customers, including independently employed, low-salary business visionaries in both urban and country ranges" (Dusuki 2008). The emergence of this new paradigm was encouraged by the success stories of microfinance innovations serving the poor throughout the 1970s and 1980s. The most cited examples are Grameen Bank in Bangladesh, the Unit Desa arrangement of Bank Rakyat Indonesia, ACCION International in the United States and Latin America and PRODEM, Bancosol's ancestor in Bolivia. The microfinance industry embraces business sector arrangements and endeavors to establish an improvement approach. It accentuates institutional and program advancements to diminish expenses and hazards and can possibly improve the standard of living for the poor in a suitable way (Ashraf 2014).

Microfinance in India started in the early 1980s with small efforts at forming informal Self-Help Groups (SHG) to provide access to much-needed savings and credit services. From this small beginning, the microfinance sector has grown significantly 
in the past decades. National bodies like the Small Industries Development Bank of India (SIDBI) and the National Bank for Agriculture and Rural Development(NABARD) are devoting significant time and financial resources to microfinance initiatives. This indicates the growing importance of the sector. The strength of the Microfinance Organizations (MFOs) in India is in the diversity of approaches and forms that have evolved over time.

After 60 years of independence, a large section of the Indian population still remains unbanked. The stark reality is that most poor people in the world still lack access to sustainable financial services, whether it is savings, credit or insurance. The great challenge before us is to address the constraints that exclude people from full participation in the financial sector. India is said to live in its villages and nearly 72 percent of our population lives in villages (as per a valid statement by the Indian Government). But in spite of this huge population in the rural areas, around 650,000 villages do not have a single bank branch. (Almost half the country is unbanked). The people in far-flung villages are completely ignorant of financial products, like insurance, which could protect the rural poor in adverse circumstances. The rural poor suffer from financial impediments, seasonal incomes, irregularity of work and job related migrations. Only 55 percent of the population have a deposit account and 9 percent have credit accounts with banks. India has the highest number of households (145 million) excluded from banking. There is on average only one bank branch per 14,000 people. Only a little less than 20 percent of the population has any kind of life insurance and 9.6 percent of the population has non life insurance coverage. Just 18 percent have debit cards and less than 2 percent possess credit cards.

With this backdrop, Jharkhand, one of the eastern states in India, poses a unique development conundrum insofar as it remains remarkably poor despite possessing an abundance of natural resources, which should, in theory increase its prospects for growth. The state boasts 40 percent of India's mineral reserves including iron ore, coal and copper, as well as the country's three largest steel plants. Still, Jharkhand has low average income levels, very high incidences of poverty and inequality, and low levels of social development in certain districts. The financial infrastructure in Jharkhand is, as one might expect, notoriously underdeveloped. Additionally, rural Jharkhand is characterized by the lack of access to credit. Therefore, various policy initiatives have been taken by the Reserve Bank of India, NABARD and Government of India to facilitate adequate institutional credit flows, particularly to the underprivileged class. NABARD has taken a number of initiatives like identifying the potential for development, the preparation of bankable area development schemes, capacity building of entrepreneurs, facilitating the state government for the speedy implementation of rural infrastructure projects, providing promotional support for the expansion of the SHG-bank linkage program etc.

To conclude, financial inclusion not only affects (in positive ways) the future economic conditions but also improves the routine life of a person and of an organization. Further, in the modern economy, the social and economic status, as well as the growth of a person, organization and a nation, depends to a large extent on the level of access to formal financial services. 
In light of the above discussion, the current work aims to put forward certain objectives that need to be addressed and fulfilled.

- Identify the key factors responsible for influencing financial inclusion and economic growth in the state of Jharkhand.

- Evaluate the efficiency of financial inclusion in terms of outreach to clients and overall customer satisfaction.

This paper tries to assess the penetration level of financial inclusion in the state of Jharkhand from both the service providers' (microfinance institutions) as well as from the service users' (borrowers) points of view. It attempts to evaluate the efficiency of financial institutions taking into account the social aspects of their performance. The remainder of this paper is organized as follows. The next section consists of the literature review. The third section explains the methodology adopted. The fourth section analyses the results obtained and the last section gives the conclusions.

\section{Literature Review}

The basic idea of microfinance is to provide credit to the people who otherwise would not have access to credit services. Microcredit programs extend small loans to poor people for self-employment projects that have the potential to generate income and allow them to take care of themselves and their families. There are various studies which confirm that microfinance programs have a significant positive impact in increasing employment and reducing poverty. In order to find out the impact of microfinance programs, impact assessment studies have been done by many authors in different countries like Bangladesh, India, Nepal, Thailand,
Ghana, Rwanda, Peru and many other countries in South Asia and Africa. "As per a World Bank overview directed for the mid-term audit of neediness mitigation and micro-finance ventures among 675 microcredit borrowers in Bangladesh there is a positive change in the monetary and economic wellbeing of the studied borrowers. The overview demonstrated that pay had expanded for 98 percent of the borrowers; 89 percent of the borrowers amassed new resources and 29 percent had bought new land, either for property or for agriculture. Food intake, lodging and clothing had also been enhanced for 89, 88 and 75 percent of the borrowers respectively. The changes had for the most part happened because of the expanded level of independent work of the ladies members" (Lavoori and Paramani 2014).

A study conducted on SAPAP self-help groups in Andhra Pradesh, India also reported an overall reduction in poverty, including reductions among the extreme poor (Kabeer 2005).

Sheokand talked about the development of Indians managing an account and the inability to give credit facilities to needy individuals. NABARD began a self-help group - bank linkage program in 1992, which was viewed as a milestone advancement in banking for poor people. It was observed that regional rural banks' concentrated more on providing credit to focused groups. Government sponsored projects had occupied a large part of the financial space and yet did not accomplish the goal of mitigating neediness. Selfhelp groups with bank linkage projects had been demonstrated to be exceptionally effective at financially strengthening the bad-tothe-bone poor, giving monetary assistance to them and setting them up to take monetary responsibility for neediness lightening. In spite of the fact that this project was not a pana- 
cea for the issues of rural destitution, it had the potential for turning into a changeless arrangement for provincial loaning in the nation with full investment from the formal banking framework and with no impedance from the government."

An investigation into the financial effects of PRADAN microfinance was completed in the state of Jharkhand to figure out the ability of microfinance to meet the customers' fundamental needs, vocational base, resource position, savings, and obligation position. 400 SHG individuals were compared with 104 non-individuals in the Godda, Dumka and Banka regions of Jharkhand. To the extent of meeting their fundamental needs, the individuals had reported a far more ideal general diet, as far as sufficiency and differing qualities of available nourishment, when contrasted with the non-individuals. SHG individuals had more elevated amounts of investment funds and lower occurrence of indebtedness. (Kabeer and Noponen 2005)

"In this ever changing world, one has to measure an organization's efficiency in order to regulate and make the necessary reforms so as to meet the organizational objectives and speed the expeditions." (From Pitt and Khandekar's 1998 study of the impact of microfinance on poverty in Bangladesh).

Chowdhury et al. (2005) examined empirically the impact of microcredit on poverty in Bangladesh. The focus was on both subjective and objective poverty and attention was paid to the time period, the clients had access to microcredit.

The execution criteria shifted fundamentally starting with one association then onto the next, since they rely on the methodological methodology, which thus relies on the determination to offer need to the supply side or the interest side of the monetary intermediation. In such a manner, there are two differentiating schools of thought: "Welfarist" and "Institutionalist." The first measures the performance of the MFIs on the premise of welfare studies. They are keen on the MFIs sway on the living state of the recipients. Welfare studies were criticized by the "Institutionalists" in view of their subjectivity, their expense and the methodological troubles they presented. They are keen on business variables, for example, the reimbursement rate, the exchange costs and the levels of money related independence and so on, one way or the other, the issue of measuring the effectiveness of the MFI's twists at assessing their execution for the effort, maintainability and their social effect" (Congo 2002). According to Chemining'wa, outreach is the effort of MFIs to provide microfinance services to the people who do not come under the umbrella of formal banking and financial institutions.

In order to measure the social impact of the MFIs, it is mandatory to focus on "Poverty." (Montgomery and Weiss 2005) defined poverty as "A lack of access by poor households to the assets necessary for a higher standard of income or welfare, regardless of whether these assets are thought of as human (access to education), natural (access to land), physical (access to infrastructure), social (access to networks of obligations) or financial (access to credit)." The evaluation of the social impact of the MFI's in abating poverty has been put forward by different scholars in many different ways. For example, according to Meyer, "Social impact is defined as attributing specific effects, impacts or the benefits of specific interventions, in this case, improved access to financial services." 


\section{Methods}

This paper suggests a set of operational indicators designed to measure the different dimensions and elements of the social performance of the MFIs. "The social performance of an organization comprises the relations of the organization with its clients and with other stakeholder groups. The measurement of social performance involves investigating the structure of an organization and its conduct in the market, and the local and wider community. In the proposed questionnaire social performance is measured through the principles, the actions and the corrective measures implemented by the MFIs" (Zeller et al. 2003). The present study analyzes the efficiency of financial inclusion in Jharkhand with the help of two questionnaires.

- The first questionnaire for service providers/facilitators examines the relationship between the social performance of the MFIs (financial inclusion determinants) with their outreach to clients.

- The second questionnaire for the service users tries to establish the relationship between the various determinants of financial inclusion and customer satisfaction for the various MFIs in four districts of Jharkhand i.e. Dhanbad, Ranchi, Jamshedpur and Bokaro.

Four important performance measurements of financial inclusion in the first questionnaire for service providers are: Geographic focus, types of services offered by the MFI, the participation level of the MFIs and access to information whose validity has been tested on the "Outreach to clients." Similarly, in the second questionnaire for service users thirteen indicators have been identified as the financial inclusion variables and their validity has been tested on the depen- dent variable "Customer satisfaction" using a linear regression model.

\section{Data Sources}

The formulation of the research questions and the hypotheses that are to be tested, the nature of the universe, the sampling frame and the sample that has been selected are all described in detail according to the objectives of the study. The population for the first questionnaire of this study included the employees of microfinance institutions, public sector banks and NGOs (service providers) who had their various branches located in Ranchi, Jamshedpur, Dhanbad and Bokaro.

The population for the second questionnaire included the customers (service users) of the above mentioned financial institutions.

The data was collected from the following institutions:

- SKS Microfinance

- Bandhan Financial Services

- Ujjivan Microfinance

- Bank of India

- IDBI Bank

- Bank of Baroda

- Indian Overseas Bank

- Global Health Education Organization NGO

For the service providers a list comprising of 250 employees had been obtained from the selected institutions in 4 districts of Jharkhand. A convenience sampling method was adopted to select the service providers. The sample size for the finite population of 250 service providers/facilitators was computed as 152 at the 5 percent confidence interval and allowing for a 95 percent level of precision. Further, an additional 10 percent 
Table 1.Sample Distribution Across 4 Districts for Service Providers

\begin{tabular}{lcc}
\hline Regions & Sample & Respondents \\
\hline Dhanbad & 50 & 41 \\
Ranchi & 56 & 44 \\
Bokaro & 32 & 23 \\
Jamshedpur & 28 & 21 \\
Total & 166 & 129 \\
\hline
\end{tabular}

was added to the sample size to cover for invalid and non-responses. Thus a sample size of 166 was selected for this study. However, out of this 166 sample of service providers/ facilitators, 31 did not participated in the survey and six responses were found to be incomplete. Thus a total of 129 questionnaires containing correctly completed information were used for our data analysis.

Similarly, for the service users a list comprising of 250 customers had been obtained from the above institutions in the above mentioned districts. A convenience sampling method was adopted to select the customers. The sample size for the finite population of 250 service users was computed to be 152 at a 5 percent confidence interval and allowing for a 95 percent level of precision. Further, an additional 10 percent was added to the sample size to cover invalid or non-respondents. Hence a sample size of 166 was arrived at for this part of the study. In the case of the service users, out of our 166 sample customers, 43 did not participate in the survey and 11 responses were been found to be incomplete. Thus a total of 112 questionnaires containing completed information were used for the data analysis.
Table 2.Sample Distribution Across 4 Districts for Service Users

\begin{tabular}{lcc}
\hline Regions & Sample & Respondents \\
\hline Dhanbad & 50 & 42 \\
Ranchi & 56 & 30 \\
Bokaro & 32 & 07 \\
Jamshedpur & 28 & 33 \\
Total & 166 & 112 \\
\hline
\end{tabular}

\section{Statistical Tools}

Simple descriptive statistical tools were applied to find out the percentages, means and standard deviations of the demographic profiles of the service providers as well as the service users. Hypothesis testing was used for analysing the data. Additionally, the study used advanced statistical tools like a multiple linear regression model calculated in SPSS 20.0 package to find out the causal effect of various variables on the outreach to clients and customer satisfaction levels separately for the service providers and service users. The number of sample respondents across the four districts is shown in Table 1 and Table 2.

\section{Survey Instrument}

Two sets of questionnaires were developed in order to evaluate the efficiency of financial inclusion in the above mentioned districts.

Questionnaire 1: It was divided into four sections

- General Information

- Profile of the Organization

- Financial Inclusion Determinants

- Outreach to Clients/coverage 
General Information. The first section collects information on the employee's age, sex, residential address and marital status.

Profile of the Organization. It contains information on the name and address of the organization and the type of business they are into.

Financial Inclusion Determinants. This section consist of questions on four important determinants of financial inclusion, the geographic focus, the types of services offered by the MFI, the participation level of the MFI and the access to information. These four factors were further subdivided into other sub-factors which were measured by related instruments based on a five point rating scale ranging from 1 strongly disagree to 5 strongly agree.

Outreach to Clients/Coverage. This section determined the outreach of the MFIs in terms of their numbers of clients or accounts that were active for the last three years which was measured on the same five point rating scale. The influence of all the financial inclusion determinants was tested on this variable in order to evaluate the efficiency of the financial inclusion.

Questionnaire 2: It was divided into 3 sections:

- Baseline information

- Financial inclusion determinants

- Customer satisfaction

Baseline Information. This section collected information on the customers / service user's age, gender and type of business activity they were associated with.

Financial Inclusion Determinants. This section contained 13 indicators which measured the customer's satisfaction on a five point rating scale ranging from 1 strongly disagree to 5 strongly agree.

Customer Satisfaction. The influence of the other critical indicators was tested on the dependent variable "Customer satisfaction" (Bihari et al. 2009).

\section{Result and Discussion}

This chapter consists of our results and analysis of the data gathered using suitable statistical tools and formulating and testing the hypotheses developed. The analysis has been done in three stages.

1. Descriptive statistics of the demographic profiles of the service providers and users

2. Analysis and hypotheses testing for the service providers

3. Analysis and hypothesis testing for the service users

Scale analysis. Once the returned questionnaires had been received and checked for suitability, the scale reliability of the developed variables were analyzed using Cronbach's alpha test on both the samples.

Reliability. Cronbach's alpha is a reliability coefficiency indicator that shows how well the variables are positively correlated to each other. The Cronbach's alpha came out to be 0.779 for the service providers and 0.801 for the service users samples which was considered to be a good sign of reliability as it was more than 0.7 (Santos 1999).

Validity. Content validity and face validity tests were also done by employing expert opinion. Five questionnaires were distributed to experts in the field of academics and finance. The experts reviewed the questionnaires and according to their suggestions the questionnaire was redesigned as required. 
Gadjah Mada International Journal of Business - September-December, Vol. 17, No.3, 2015

Table 3. Mean and Standard Deviations of the Responses (Service Providers)

\begin{tabular}{lcc}
\hline Variables & Mean & $\begin{array}{c}\text { Standard } \\
\text { Deviation }\end{array}$ \\
\hline Customers targetedin rural areas & 3.27 & 0.511 \\
Customers targeted in urban/semi-urban areas & 4.24 & 0.528 \\
Customers targeted for socio-economic development of the region & 3.98 & 0.535 \\
Literacy training & 3.95 & 0.618 \\
Marketinformation & 4.66 & 0.599 \\
Social awareness training & 4.12 & 0.526 \\
Legal counsel & 2.23 & 0.430 \\
Participation in govemment meetings & 3.35 & 0.524 \\
Participation in non-govemment activities & 3.07 & 0.549 \\
Participation in social/political movements & 3.59 & 0.512 \\
Decision making influenceon government organizations & 2.44 & 0.497 \\
Decision making influence in the private/NGO sector & 4.51 & 0.522 \\
Receiptof transaction statements & 4.77 & 0.416 \\
Passbook maintenance for savings & 4.69 & 0.461 \\
Passbook maintenance for loans & 4.67 & 0.571 \\
Client participation in business decisions of the MFIs & 3.57 & 0.531 \\
Satisfaction with the number of clients or accounts that are active in the last3 years & 4.72 & 0.511 \\
\hline
\end{tabular}

Table 4. Mean and Standard Deviations of the Responses (Service Users)

\begin{tabular}{lcc}
\hline Variables & Mean & $\begin{array}{c}\text { Standard } \\
\text { Deviation }\end{array}$ \\
\hline Client specific needs & 4.04 & 0.570 \\
Client personal attention & 4.03 & 0.469 \\
Management supportto employees & 3.98 & 0.514 \\
Safety of trans actions & 4.26 & 0.691 \\
Trustin employees & 4.64 & 0.547 \\
Efficientresponse to client requests & 4.48 & 0.705 \\
Willingness to help customers & 4.66 & 0.632 \\
Promptservice & 4.75 & 0.602 \\
Sympathetic attitude to clients & 4.16 & 0.530 \\
Accuracy of records maintenance & 4.71 & 0.523 \\
Convenient business hours & 2.12 & 0.559 \\
Client specific loan products & 3.65 & 0.521 \\
Client satisfaction with the interest rates & 2.97 & 0.515 \\
Iwould prefer to use the services of MFIs and in future I willwith confidence & 4.47 & 0.640 \\
\hline
\end{tabular}


Descriptive statistics of demographic profile. Table 3 and Table 4 give the means and standard deviations of the respondents (service providers and service users).

The demographic profile represents the pattern of the respondents in terms of their age, gender, marital status and occupation comprising the service providers and service users/customers in Tables 5 and 6.

It can be observed from Table 5 that out of the total of 129 respondents from the service providers group, most of them were in the age groups of $30-40$ (44.18 percent)

Table 5. Service Providers/MFIs

\begin{tabular}{lcc}
\hline Dimensions & Particulars & Percentage \\
\hline Age & $20-30$ & 41.86 \\
& $30-40$ & 44.18 \\
& $40-50$ & 13.96 \\
Gender & 50 and above & 0.00 \\
& Male & 86.04 \\
Marital status & Female & 13.96 \\
& Unmarried & 32.55 \\
& Married & 67.45 \\
\hline
\end{tabular}

Table 6. Service Users

\begin{tabular}{lcc}
\hline Dimensions & Particulars & Percentage \\
\hline Age & $20-30$ & 38.39 \\
& $30-40$ & 37.50 \\
& $40-50$ & 20.53 \\
& 50 and above & 3.58 \\
Gender & Male & 30.35 \\
& Female & 69.65 \\
Type of & Salaried & 12.50 \\
occupation & Self-employed & 87.50 \\
\hline
\end{tabular}

and $20-30$ (41.86 percent), a few were in the age group of 40-50 (13.96 percent) and none in the 50 and above group. Almost, 87 percent were males and only 13 percent females.

In the case of the customers, it was observed that the highest number of microloan seekers were in the age groups of 20-30 and 30-40.

Around 70 percent of the microfinance users were females, as a result of which most of them experienced an increase in their decision making roles in the areas of family planning, marriage of children, buying and selling property and sending their daughters to school (Ashe and Parrot 2001). This showed that microfinance created a strong impact on the empowerment of women. It could also be observed that the number of self-employed customers (88 percent) was much higher than the number of salaried clients.

\section{Analysis and Hypotheses Testing for the Service Providers}

Four factors were taken into consideration namely, the geographic focus, the types of services, the participation level of the MFIs and the access to information.

\section{Development of Hypotheses}

Hypothesis 1: Geographic focus has a positive impact on the outreach or number of clients served (coverage).

Hypothesis 2: Types of services offered by the MFIs affects the outreach to clients.

Hypothesis 3: Participation level of the MFIs affects the outreach/ coverage.

Hypothesis 4: Access to information has a positive impact on the outreach to clients. 


\section{Geographic Focus}

Three factors have been identified under this dimension namely customers targeted in rural areas, customers targeted in urban/ semi-urban areas and customers targeted for socio-economic development of the region. Regression analysis was carried out to find out the causal effect of each of these three factors on the outreach to the clients. The following regression model was used to measure the indicators of geographic focus on the coverage or outreach to the clients:

$$
\begin{aligned}
\text { Outreach }= & \alpha+\beta_{1} \text { customers in rural areas } \\
& +\beta_{2} \text { customers in urban } / \text { semi- } \\
& \text { urban areas }+\beta_{3} \text { customers tar- } \\
& \text { geted for socio-economic de- } \\
& \text { velopment of the region }+\varepsilon_{1}
\end{aligned}
$$

where, $\alpha$ is the intercept, $\beta_{1,} \beta_{2}, \beta_{3}$ the regression coefficients and $\varepsilon_{1}$ is the error term.
Table 7 shows the regression values of the independent variables of geographic focus. It clearly shows that the coefficients of customers targeted in rural areas, customers targeted in urban areas and customers targeted for socio-economic development of the region are significant at the 1 percent significance level. The adjusted $\mathrm{R}^{2}$ value is 0.819 and the higher $\mathrm{F}$-value being significant at the 1 percent level shows the good fit of the regression model. This suggests that geographic focus had a positive impact on the number of clients/coverage.

\section{Types of Services Offered by the MFIs}

The four factors identified under this dimension were - literacy training, market information, social awareness training and legal counsel. Regression analysis was done to find out the causal effect of each of these four factors on the outreach to the clients.

\section{Table 7. Regression Analysis of Geographic Focus}

\section{Dependent Variable: Outreach (Number of Clients Served)}

\begin{tabular}{lc}
\hline Variables & Coefficients \\
\hline Customers targeted in rural areas & $0.761^{*}(13.784)$ \\
Customers targeted in urban/semi-urban areas & $0.789^{*}(8.798)$ \\
Customers targeted for socio-economic development of the region & $0.694^{*}(7.648)$ \\
Adjusted $\mathrm{R}^{2}$ & 0.819
\end{tabular}

Analysis of Variance

\begin{tabular}{lccccc}
\hline Model & Sum of Squares & Df & Mean Square & F & Sig. \\
\hline Regression & 20.948 & 3 & 3.998 & $194.844^{*}$ & 0.000 \\
Residual & 2.781 & 125 & 0.112 & & \\
\hline
\end{tabular}

Note: $*$ and ${ }^{* *}$ implies 1 and 5 percent significance level respectively, t-values are in the parentheses. 
The following regression model had been used to measure the indicators of the types of services offered by the coverage or outreach to the clients:

$$
\begin{aligned}
\text { Outreach }= & \alpha+\beta_{1} \text { literacy training }+\beta_{2} \\
& \text { market information }+\beta_{3} \text { so- } \\
& \text { cial awareness training }+\beta_{4} \\
& \text { legal counsel }+\varepsilon_{1}
\end{aligned}
$$

where, $\alpha$ is the intercept, $\beta_{1,} \beta_{2}, \beta_{3,} \beta_{4}$ the regression coefficients and $\varepsilon_{1}$ is the error term.

The result of the regression analysis in Table 8 (0.886) demonstrates that market information is highly significant whereas literacy training and social awareness training are less significant, except for the legal counsel. Legal counsel showed a negative impact on the outreach to clients and the financial inclusion process as the coefficient was insignificant. But, overall the types of training services offered by these institutions were really helpful in achieving a strong customer base and fulfilled the objective of financial inclusion.

\section{Participation level of the MFIs}

There were five factors identified under the participation level of the MFIs' influence on the outreach to the clients.

Hence, a regression analysis was used to identify the participation level factor that affected the outreach to the clients:

$$
\begin{aligned}
\text { Outreach }= & \alpha+\beta_{1} \text { participation in gov- } \\
& \text { ernment meetings }+\beta_{2} \text { par- } \\
& \text { ticipation in non-governmen- } \\
& \text { tal activities }+\beta_{3} \text { participation } \\
& \text { in social/political movements } \\
& +\beta_{4} \text { decision making influ- } \\
& \text { ence in government organiza- } \\
& \text { tions }+\beta_{5} \text { decision making in- } \\
& \text { fluence in private/NGO sec- } \\
& \text { tor }+\varepsilon_{1}
\end{aligned}
$$

Table 8. Regression Analysis of Types of Services Offered

Dependent Variable: Outreach (Number of Clients Served)

\begin{tabular}{lc}
\hline Variables & Coefficients \\
\hline Literacy training & $0.076^{* *}(2.074)$ \\
Market information & $0.709^{*}(14.441)$ \\
Social awareness training & $0.078^{* *}(2.437)$ \\
Legal counsel & $-0.089(-0.410)$ \\
Adjusted $\mathrm{R}^{2}$ & 0.886
\end{tabular}

Analysis of Variance

\begin{tabular}{lccccc}
\hline Model & Sum of Squares & Df & Mean Square & F & Sig. \\
\hline Regression & 19.498 & 4 & 4.101 & $208.784^{*}$ & 0.000 \\
Residual & 2.817 & 131 & 0.010 & & \\
\hline
\end{tabular}

Note: ${ }^{*}$ and ${ }^{* *}$ implies 1 and 5 percent significance level respectively, t-values are in the parentheses. 
Table 9. Regression Analysis for Participation Level of MFIs

Dependent Variable: Outreach (Number of Clients Served)

\begin{tabular}{lc}
\hline Variables & Coefficients \\
\hline Participation in government meetings & $0.043^{* *}(1.413)$ \\
Participation in non-government activities & $0.091^{* *}(4.612)$ \\
Participation in social/political movements & $0.078^{* *}(2.417)$ \\
Decision making influence in government organizations & $-0.203(-1.140)$ \\
Decision making influence in the private/NGO sector & $0.019^{* *}(1.147)$ \\
Adjusted $\mathrm{R}^{2}$ & 0.790
\end{tabular}

Analysis of Variance

\begin{tabular}{lccccc} 
Model & Sum of Squares & Df & Mean Square & F & Sig. \\
\hline Regression & 18.948 & 4 & 4.010 & $198.684^{*}$ & 0.000 \\
Residual & 2.730 & 136 & 0.211 & &
\end{tabular}

Note: ${ }^{*}$ and ${ }^{* *}$ implies 1 and 5 percent significance level respectively, t-values are in the parentheses.

where, $\alpha$ is the intercept, $\beta_{1,} \beta_{2}, \beta_{3,} \beta_{4} \beta_{5}$ the regression coefficients and $\varepsilon_{1}$ is the error term.

Table 9 shows the regression values of the five independent variables on the outreach. It clearly shows the significance of the regression coefficients at the 5 percent significance level, except for the decision-making power in government organizations which showed a negative impact on the outreach to clients. The negative relationship may be attributed to the reluctance on the part of the government to have the MFIs participating in their decision making processes. But the overall impact of the participation level of the MFIs in various government and non-government activities was positive, and they do play a role in reaching out to a significantly large number of clients and providing loans for the betterment of the masses.

\section{Access to Information}

The four factors identified under this dimension were - receipt of financial transaction statements, passbook maintenance for savings, passbook maintenance for loans and clients participation in business decisions. Regression analysis was done to find the causal effect of each of these four factors on the outreach to the clients. The following regression model was used:

$$
\begin{aligned}
\text { Outreach }= & \alpha+\beta_{1} \text { receipt of transaction } \\
& \text { statements }+\beta_{2} \text { passbook } \\
& \text { maintenance for savings }+\beta_{3} \\
& \text { passbook maintenance for } \\
& \text { loans }+\beta_{4} \text { client participation } \\
& \text { in business decisions of } \\
& \text { MFIs }+\varepsilon_{1}
\end{aligned}
$$

where, $\alpha$ is the intercept, $\beta_{1,} \beta_{2}, \beta_{3}, \beta_{4}$ the regression coefficients and $\varepsilon_{1}$ is the error term. 
Table 10. Regression Analysis of Access to Information

\begin{tabular}{|c|c|c|c|c|c|}
\hline \multicolumn{6}{|c|}{ Dependent Variable: Outreach (Number of Clients Served) } \\
\hline \multicolumn{4}{|l|}{ Variables } & \multicolumn{2}{|c|}{ Coefficients } \\
\hline \multicolumn{4}{|c|}{ Receipt of transaction statements } & \multicolumn{2}{|c|}{$0.861 *(14.208)$} \\
\hline \multicolumn{4}{|c|}{ Passbook maintenance for savings } & \multicolumn{2}{|c|}{$0.869 *(15.957)$} \\
\hline \multicolumn{4}{|c|}{ Passbook maintenance for loans } & \multicolumn{2}{|c|}{$0.843 *(15.342)$} \\
\hline \multicolumn{4}{|c|}{ Client participation in business decisions of the MFIs } & \multicolumn{2}{|c|}{$0.706 *(14.891)$} \\
\hline \multicolumn{4}{|c|}{ Adjusted $\mathrm{R}^{2}$} & \multicolumn{2}{|c|}{0.883} \\
\hline \multicolumn{6}{|c|}{ Analysis of Variance } \\
\hline Model & Sum of Squares & Df & Mean Square & $\mathbf{F}$ & Sig. \\
\hline Regression & 18.868 & 4 & 4.225 & $199.211^{*}$ & 0.000 \\
\hline Residual & 2.765 & 135 & 0.221 & & \\
\hline
\end{tabular}

Note: $*$ and $* *$ implies 1 and 5 percent significance level respectively, t-values are in the parentheses

It can be clearly ascertained from the table that all four factors were highly significant at the 1 percent significance level. The adjusted value of $\mathrm{R}^{2}$ was 0.883 , which is on the higher side, and a high value of $F$ at 1 percent shows the good fit of the regression model. The hypothesis developed tested positive showing the usefulness of information accessibility on financial inclusion.

\section{Analysis and Hypotheses Testing for the Service Users}

Thirteen indicators had been identified as financial inclusion variables and their validity was tested on the dependent variable "Customer satisfaction" using a linear regression model.

\section{Development of Hypothesis}

$H_{i}$ : Microfinance operations have a positive impact on customer satisfaction.
The following regression model was used to measure the indicators of financial inclusion on customer satisfaction.

$$
\begin{aligned}
& \text { Customer satisfaction }=\alpha+\beta_{1} \text { client } \\
& \text { specific needs }+\beta_{2} \text { client } \\
& \text { personal attention }+\beta_{3} \\
& \text { management support to } \\
& \text { employees }+\beta_{4} \text { safety of } \\
& \text { transactions }+\beta_{5} \text { trust on } \\
& \text { employees }+\beta_{6} \text { efficient } \\
& \text { responses to client requests } \\
& +\beta_{7} \text { willingness to help } \\
& \text { customers }+\beta_{8} \text { prompt } \\
& \text { service }+\beta_{9} \text { sympathetic } \\
& \text { attitude towards clients }+ \\
& \beta_{10} \text { accuracy of records } \\
& \text { maintenance }+\beta_{11} \text { conve- } \\
& \text { nient business hours }+\beta_{12} \\
& \text { client specific loan products } \\
& +\beta_{13} \text { interest rate } \\
& \text { affordability }+\varepsilon_{1}
\end{aligned}
$$


Table 11. Regression Analysis for Customer Satisfaction

Dependent Variable: Customer Satisfaction

\begin{tabular}{lc}
\hline Variables & Coefficients \\
\hline Client specific needs & $0.317^{* *}(2.146)$ \\
Client personal attention & $0.071^{* *}(3.041)$ \\
Management support for employees & $0.049^{* *}(2.498)$ \\
Safety of transactions & $0.871 * *(4.672)$ \\
Trust in employees & $0.543^{* *}(3.102)$ \\
Efficient response to client requests & $0.231^{*}(8.958)$ \\
Willingness to help customers & $0.702^{*}(11.448)$ \\
Prompt service & $0.630^{*}(5.553)$ \\
Sympathetic attitude to clients & $0.103^{* *}(1.669)$ \\
Accuracy of records maintenance & $0.836^{*}(15.590)$ \\
Convenient business hours & $-0.101(-0.401)$ \\
Client specific loan products & $0.082^{* *}(4.960)$ \\
Interest rate affordability & $-0.008(-1.046)$ \\
Adjusted R & 0.886
\end{tabular}

Analysis of Variance

\begin{tabular}{lccccc}
\hline Model & Sum of Squares & Df & Mean Square & F & Sig. \\
\hline Regression & 19.948 & 11 & 4.200 & $197.844^{*}$ & 0.000 \\
Residual & 3.781 & 131 & 0.080 & & \\
\hline
\end{tabular}

Note: $*$ and ${ }^{* *}$ implies 1 and 5 percent significance level respectively, $\mathrm{t}$-values are in the parentheses.

where, $\alpha$ is the intercept, $\beta_{1} \beta_{2}, \beta_{3}, \beta_{4}, \beta_{5}, \beta_{6}$, $\beta_{7}, \beta_{8}, \beta_{9}, \beta_{10}, \beta_{11}, \beta_{12}, \beta_{13}$ are the regression coefficients and $\varepsilon_{1}$ is the error term.

Table 11 shows the regression values of the independent variables. The adjusted $\mathrm{R}^{2}$ value is 0.886 and the higher value of $\mathrm{F}$ being significant at 1 percent shows the good fit of the regression model used to understand the dependency of the financial inclusion variables on "Customer satisfaction." It clearly shows that the coefficient of efficient responses to client requests, willingness to help customers, prompt service delivery to clients and accuracy in records maintenance are highly significant at the 1 percent significance level.

On the other hand the coefficient of clients' specific needs, personal attention to clients, management support to employees, safety of transactions, trust in the MFIs' employees and clients' specific loan products are significant at the 5 percent significance 
level. It is quite clear from the analysis that the higher the impact of these factors is, the higher will be the customers' loyalty towards the MFIs, which in turn will promote financial inclusion in the region.

However, two factors - convenient business hours for, and the interest rate affordability of, the clients, are both insignificant. The negative relationship of business hours on customer satisfaction may be attributed to the bureaucratic working style of the public sector banks.

The negative relationship of interest rates affordability can be attributed to the very high rates charged by the microfinance institutions, which sometimes makes it difficult for the customers to repay on time.

Overall, the financial inclusion determinants had a positive impact on the customer satisfaction as developed in our hypothesis and were very crucial for the financial inclusion initiative in the state of Jharkhand.

\section{Conclusion}

This study identified the key factors which had a profound influence on the performance of the microfinance institutions and as well as the factors which influenced the customers' satisfaction level. Though there is no dearth of literature related to microfinance, and impact assessment studies have been done by many authors in different countries like Bangladesh, India, Pakistan, Nepal, Thailand, Ghana, Rwanda, Peru and many other countries in South Asia and Africa, this study added to the available literature.

Some research works' emphasis were more on the financial performance of the microfinance institutions, while some others on the outreach to the clients. There were limited studies which analyzed the efficiency of the financial inclusion from the performance as well as from the customers' satisfaction point of view. This study contributes to the literature by determining the indicators responsible for effective financial inclusion and economic growth in the state of Jharkhand.

\section{Major Findings of The Study}

- Geographic focus / frequency and type of customers targeted by the MFIs have a positive impact on the outreach to clients which in turn positively affects the level of financial inclusion activity in any region.

- The quality and type of training services offered by these institutions are really helpful in achieving a strong base of customers and fulfilling the objective of financial inclusion.

- The influence of the participation level of the MFIs in government and non-governmental activities has a significant impact on the financial inclusion.

- The financial inclusion determinants have a positive impact on the customer satisfaction levels as developed in our hypothesis and are very crucial for the financial inclusion initiative in Jharkhand.

\section{Limitations of the Study}

The current study is not free from certain limitations. The present study was restricted to the list of factors that determine the success of financial inclusion.

Data were collected from only four districts of Jharkhand i.e. Dhanbad, Bokaro, Jamshedpur and Ranchi, keeping in mind the 
convenience and accessibility of the researchers. Thus, the question of inadequate representation cannot be ruled out.
Finally this being a case study in Jharkhand, its generalization across the country will be rather limited.

\section{References}

ADB. 2008. News from ADB Bangladesh. A Quarterly Newsletter (September).

Ashe, J., L. Parrott. 2002. PACT's women's empowerment program in Nepal: A savings-and literacy-led alternative to financial building. Journal of Microfinance/ESR Review 4 (2): 137-162.

Ashraf, M. A. 2014. Fragility of microfinance institutions (MFIs) in Bangladesh and its implications for poverty-focused paradigm-shift. An exploratory study. Research on Humanities and Social Sciences 4 (16), 21-28. (1-9)

Bihari, S. C., S. K. Roy, and K. Bhattacharya. 2010. Customer Satisfaction Survey in Selected Microfinance Institution. http://www.iibf.org.in/documents/reseach-report/Report-21.pdf.

Chemining'wa, A. T. 2013. The Relationship between MFI outreach services and financial sustainability in Kenya. Doctoral Dissertation. Scholl of Business, University Nairobi.

Chowdhury, M. J. A., D. Ghosh, and R. E. Wright. 2005. The impact of microcredit on poverty: Evidence from Bangladesh. Progress in Development Studies 5 (4): 298-309.

Congo, Y. 2002. Performance of microfinance institutions in Burkina Faso (No. 2002/01). WIDER Discussion Papers. World Institute for Development Economics (UNU-WIDER).

Kabeer, N. 2005. Is microfinance a 'magic bullet' for women's empowerment? Analysis of findings from South Asia. Economic and Political Weekly: 4709-4718.

Kabeer, N., and H. Noponen. 2005. Social and Economic Impacts of PRADAN's Self Help Group Microfinance and Livelihoods Promotion Program: Analysis From Jharkhand, India (No. 23755).

Lavoori, V., and R. N. Paramanik. 2014. Microfinance impact on women's decision making: A case study of Andhra Pradesh. Journal of Global Entrepreneurship Research 4 (1): 1-13.

Meyer, R. L. 2002. Track Record of Financial Institutions in Assisting the Poor in Asia. Singapore: ADB Institute.

Pitt, M. M., and S. R. Khandker. 1998. The impact of group-based credit programs on poor households in Bangladesh: Does the gender of participants matter? Journal of Political Economy 106 (5): 958-996.

Santos, J. R. A. 1999. Cronbach's Alpha: A tool for assessing the reliability of scales. Journal of Extension 37 (2): $1-5$.

Sheokand, S. M. 2000. Reorienting banking with the poor: The SHG bank linkage way. In K. Basu \& K. Jindal (Eds.), Microfinance Emerging Challenges. Tata McGraw Hill Publications.

Van Balkom, V., R. Walczuch, and F. Gassmann. 2009. Open Information Systems and Their Effect on Microfinance Institutes. Maastricht University.

Dusuki, W. A. 2008. Banking for the poor: The role of islamic banking in microfinance initiatives. Humanomics 24 (1): 49-66.

Weiss, J., and H. Montgomery. 2005. Great expectations: Microfinance and poverty reduction in Asia and Latin America. Oxford Development Studies 33 (3-4): 391-416.

Zeller, M., C. Lapenu, and M. Greeley. 2003. Social Performance Indicators Initiative (SPI). Initiating memorandum, March. Comite d'Echange, de Reflexion et d'Information sur les systemes d'Epargne-credit (CERISE). 


\section{Appendix 1}

Questionnaire 1. For Service Providers

District:

Date of Interview:

Interview Start time:

Interview End Time:

This survey is a part of the project titled "Evaluating the Efficiency of Financial Inclusion in Jharkhand." Survey respondents include those who are actively engaged in microfinance/microcredit. All of your answers will be confidential. We truly hope that you will participate in this survey, as your views are extremely important for the study

\section{SECTION A: GENERAL INFORMATION}

A.1. Name
A. 2. Age:
(i) 21-30
(ii) $31-40$
(iii) $41-50$
(iv) $51 \&$ above
A.3. Gender:
(i) Male
(ii) Female

A. 4. Residential Address
A.5. Marital Status:
(i) Unmarried
(ii) Married
(iii) Spouse/Partner Died
(iv) Divorced

\section{SECTION B: PROFILE OF THE ORGANIZATION}

B. 1. Name of the Organization/Institution

B.2. Date of Establishment

B.3. Address of the Organization

B. 4. Type of Business

\section{SECTION C: DETERMINANTS OF FINANCIAL INCLUSION}

C.1 Geographic focus:

\begin{tabular}{|l|l|l|l|l|c|}
\hline \multicolumn{1}{|c|}{ Statement } & $\begin{array}{c}\text { None } \\
(1)\end{array}$ & $\begin{array}{c}\text { Less than 30\% } \\
\text { of the clients } \\
(2)\end{array}$ & $\begin{array}{c}\text { About 30- } \\
60 \%(3)\end{array}$ & $\begin{array}{c}\text { About } \\
60-90 \% \\
(4)\end{array}$ & $\begin{array}{c}\text { More } \\
\text { than } \\
90 \% / \mathrm{Al} \\
1\end{array}$ \\
\hline $\begin{array}{l}\text { The frequency of customers } \\
\text { targeted by the MFI in rural } \\
\text { areas is }\end{array}$ & & & & & \\
\hline $\begin{array}{l}\text { The frequency of customers } \\
\text { targeted by the MFI in Urban/ } \\
\text { semi urban areas is }\end{array}$ & & & & & \\
\hline $\begin{array}{l}\text { The frequency of customers } \\
\text { targeted by the MFI for socio- } \\
\text { economic development of the } \\
\text { region is }\end{array}$ & & & & & \\
\hline
\end{tabular}




\section{Appendix 1 (Continued)}

C. 2 Types of services offered by the MFIs:

\begin{tabular}{|l|l|l|l|l|l|}
\hline \multicolumn{1}{|c|}{ Statement } & Very poor (1) & Poor (2) & Fair (3) & Good (4) & Very good (5) \\
\hline $\begin{array}{l}\text { The literacy training } \\
\text { provided by the MFI to } \\
\text { customers is }\end{array}$ & & & & & \\
\hline $\begin{array}{l}\text { The market information } \\
\text { provided by the MFI is }\end{array}$ & & & & & \\
\hline $\begin{array}{l}\text { The social awareness } \\
\text { training provided by the } \\
\text { MFI is }\end{array}$ & & & & & \\
\hline $\begin{array}{l}\text { The legal counsel given } \\
\text { by the MFI is }\end{array}$ & & & & & \\
\hline
\end{tabular}

C.3 Participation of the MFIs:

\begin{tabular}{|l|l|l|l|l|l|}
\hline \multicolumn{1}{|c|}{ Statement } & $\begin{array}{c}\text { Never } \\
(1)\end{array}$ & $\begin{array}{c}\text { Rarely } \\
\text { (2) }\end{array}$ & $\begin{array}{c}\text { Sometimes } \\
\text { (3) }\end{array}$ & $\begin{array}{c}\text { Most of the } \\
\text { time (4) }\end{array}$ & $\begin{array}{c}\text { Always } \\
\text { (5) }\end{array}$ \\
\hline $\begin{array}{l}\text { Does the MFI participate in } \\
\text { planned meetings of the } \\
\text { government }\end{array}$ & & & & & \\
\hline $\begin{array}{l}\text { Does the MFI participate in } \\
\text { planned meetings of the non- } \\
\text { governmental organizations }\end{array}$ & & & & & \\
\hline $\begin{array}{l}\text { Does the MFI participate in } \\
\text { social/political movements with a } \\
\text { focus to improve the situation of } \\
\text { the poor in society }\end{array}$ & & & & & \\
\hline $\begin{array}{l}\text { The MFI's influence in decision } \\
\text { making regarding government } \\
\text { organizations in the operational } \\
\text { area of the MFI }\end{array}$ & & & & & \\
\hline $\begin{array}{l}\text { The MFI's influence in decision } \\
\text { making regarding the } \\
\text { private/NGO sector in the } \\
\text { operational area of the MFI }\end{array}$ & & & & & \\
\hline
\end{tabular}




\section{Appendix 1 (Continued)}

\section{C.4 Access to information:}

\begin{tabular}{|l|l|l|l|l|l|}
\hline \multicolumn{1}{|c|}{ Statement } & $\begin{array}{c}\text { Strongly } \\
\text { Disagree (1) }\end{array}$ & $\begin{array}{c}\text { Disagre } \\
\text { e } \\
(2)\end{array}$ & $\begin{array}{c}\text { Neither } \\
\text { agree nor } \\
\text { disagree (3) }\end{array}$ & $\begin{array}{c}\text { Agree } \\
\text { (4) }\end{array}$ & $\begin{array}{c}\text { Strongly } \\
\text { agree } \\
\text { (5) }\end{array}$ \\
\hline $\begin{array}{l}\text { Clients receive written } \\
\text { statements on each of their } \\
\text { financial transactions }\end{array}$ & & & & & \\
\hline $\begin{array}{l}\text { Passbook maintenance for } \\
\text { savings by the clients is } \\
\text { helpful }\end{array}$ & & & & & \\
\hline $\begin{array}{l}\text { Passbook maintenance for } \\
\text { their loans is helpful for the } \\
\text { clients }\end{array}$ & & & & & \\
\hline $\begin{array}{l}\text { Clients get an opportunity to } \\
\text { participate in the business } \\
\text { decisions of the MFI, e.g. } \\
\text { related to the loan repayment } \\
\text { schedule }\end{array}$ & & & & & \\
\hline
\end{tabular}

\section{SECTION D: OUTREACH TO CLIENTS/COVERAGE:}

You are satisfied with the number of clients or accounts that are active for the last 3 years

\begin{tabular}{c|c|c|c|c}
\hline ;trongly Disagree & Disagree & Neither agree nor disagree & Agree & Strongly agree \\
$(1)$ & $(2)$ & $(3)$ & $(4)$ & (5) \\
\hline
\end{tabular}




\section{Appendix 2}

\section{Questionnaire 2. For Service Users}

\section{District:}

Date of Interview:

Interview Start Time:

Interview End Time:

This survey is part of the project titled "Evaluating the Efficiency of Financial Inclusion in Jharkhand." Survey respondents include those who have received loans or are in the process of receiving credit from the microfinance institutions. All of your answers will be confidential. We truly hope that you will participate in this survey, as your views are extremely important for the study.

\section{SECTION A - BASELINE INFORMATION:}

$\mathrm{N} \quad \mathrm{a}$

$\mathrm{m}$

e

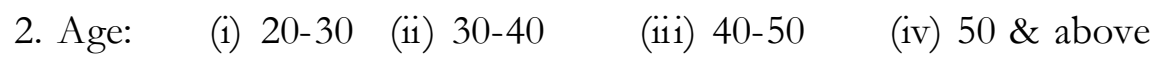

3. Gender: (i) Male: (ii) Female:

4. Residence:
5. Occupation:
(i) Service:
(ii) Self employed:

6. What kind of business activity are you engaged in? 


\section{Appendix 2(Continued)}

\section{SECTION B - INDICATORS OF FINANCIAL INCLUSION ACTIVITY:}

\begin{tabular}{|c|c|c|c|c|}
\hline Statements & $\begin{array}{cc}\text { Strongly } & \text { Disagree } \\
\text { Disagree } & (2) \\
(1) & \end{array}$ & $\begin{array}{c}\text { Neither } \\
\text { Agree nor } \\
\text { Disagree } \\
\text { (3) }\end{array}$ & $\begin{array}{l}\text { Agree } \\
\text { (4) }\end{array}$ & $\begin{array}{l}\text { Strongly } \\
\text { Agree } \\
\text { (5) }\end{array}$ \\
\hline \multicolumn{5}{|l|}{$\begin{array}{l}\text { Employees of the MFI understand your } \\
\text { specific needs }\end{array}$} \\
\hline \multicolumn{5}{|l|}{$\begin{array}{l}\text { Employees of the MFI give you personal } \\
\text { ittention }\end{array}$} \\
\hline \multicolumn{5}{|l|}{$\begin{array}{l}\text { Employees get adequate support from } \\
\text { nanagement to do their jobs well }\end{array}$} \\
\hline \multicolumn{5}{|l|}{$\begin{array}{l}\text { You can feel safe in your transactions } \\
\text { with the MFI's employees }\end{array}$} \\
\hline \multicolumn{5}{|l|}{ You can trust the employees of the MFI } \\
\hline \multicolumn{5}{|l|}{$\begin{array}{l}\text { Employees of the MFI are never too busy } \\
\text { o respond to your requests }\end{array}$} \\
\hline \multicolumn{5}{|l|}{$\begin{array}{l}\text { Employees of the MFI are always willing } \\
\text { o help customers }\end{array}$} \\
\hline \multicolumn{5}{|l|}{$\begin{array}{l}\text { You do not receive prompt service from } \\
\text { he MFI }\end{array}$} \\
\hline \multicolumn{5}{|l|}{$\begin{array}{l}\text { When you have problems, the MFI is } \\
\text {;ympathetic and reassuring }\end{array}$} \\
\hline \multicolumn{5}{|l|}{ The MFI maintains accurate records } \\
\hline \multicolumn{5}{|l|}{ The MFI has convenient business hours } \\
\hline \multicolumn{5}{|l|}{$\begin{array}{l}\text { MFI provides loan products specific to } \\
\text { rour requirements }\end{array}$} \\
\hline $\begin{array}{l}\text { You are comfortable with the current } \\
\text { nterest rates of the MFI }\end{array}$ & & & & \\
\hline
\end{tabular}

\section{SECTION C - CUSTOMER SATISFACTION LEVEL:}

\begin{tabular}{c|c|c|c|c|}
\hline Strongly & Disagree & Neither Agree nor & Agree & Strongly Agree \\
Disagree & $(2)$ & Disagree & (4) \\
$(1)$ & & $(3)$ & & \\
\hline
\end{tabular}

